\title{
APPLICATION OF SILVER CONDUCTING GLASSES TO SOLID STATE BATTERIES AND SENSORS
}

\author{
LIU JUN, J. PORTIER, B. TANGUY, J.J. VIDEAU \\ Laboratoire de Chimie du Solide \\ M. AIT ALLAL, J. MORCOS, J. SALARDENNE \\ Laboratoire d'Etude des Matériaux pour la MicroElectronique, Université de Bordeaux I, \\ 351 Cours de la Libération, 33405 Talence Cédex (France) \\ (Received February 20, 1990; in final form March 12, 1990)
}

\begin{abstract}
Fast silver ion conducting glasses as electrochemical devices have been tested. A silver iodine battery using a silver ionic conducting glass $\left(\mathrm{AgPO}_{3}-\mathrm{Ag}_{2} \mathrm{~S}-\mathrm{AgI}\right)$ has been studied. The interaction of some gases $\left(\mathrm{O}_{2}, \mathrm{Cl}_{2}, \mathrm{H}_{2} \mathrm{~S}\right)$ with the electrochemical chains: $\mathrm{Pt} / \mathrm{Sb}_{2} \mathrm{~S}_{3^{-}} \mathrm{AgI}$ (glass)/ $\mathrm{Ag}$ and $\mathrm{Pt} / \mathrm{AgCl}$ (thin film) $/ \mathrm{Sb}_{2} \mathrm{~S}_{3^{-}}$ $\mathrm{AgI}$ (glass)/ $\mathrm{Ag}$ has been investigated. Finally, the behavior of thin films of $\mathrm{Ag}_{2} \mathrm{~S}_{3}-\mathrm{Ag}_{2} \mathrm{~S}$-CdS glasses as sensitive membranes for $\mathrm{Cd}$ detection in solution has been tested on $\mathrm{MIS}$ structures $\mathrm{Au} / \mathrm{Si} / \mathrm{SiO}_{2} /$ Membrane/Cd in solution/Reference electrode.
\end{abstract}

\section{INTRODUCTION}

Silver ions are well known to possess a very high mobility in some solid phases. $\mathrm{RbAg}_{4} \mathrm{I}_{5}$, for example, has a conductivity at room temperature is as high as 0.3 $\Omega^{-1} \mathrm{~cm}^{-1}$. But the stability of these materials is very poor; silver rubidium iodide decomposes at $18{ }^{\circ} \mathrm{C}$ and is not very stable towards moisture and iodine.

New solid electrolytes have been prepared by reaction of a glass former $\left(\mathrm{As}_{2} \mathrm{~S}_{3}\right.$, $\mathrm{Sb}_{2} \mathrm{~S}_{3}, \mathrm{AgPO}_{3} \ldots$. . ) with $\mathrm{AgI}$ and $\mathrm{Ag}_{2} \mathrm{~S}$ mixtures. These glassy electrolytes have conductivities reaching $10^{-2}$ to $10^{-1} \Omega^{-1} \mathrm{~cm}^{-1}$ at room temperature ${ }^{1,2.3}$. Although the conductivity of these glasses is less (10 to 100 times lower) than $\operatorname{RbAg}_{4} \mathrm{I}_{5}$, they possess some advantages: good stability, easy to shape, possibility to prepare thin films.

The present paper deals with the use of some of these glasses in applications such as solid batteries and chemical sensors.

Saito and Kashihara have proposed the use of $\mathrm{RbAg}_{4} \mathrm{I}_{5}$ in a silver iodine battery ${ }^{4}$. Compared to lithium batteries, they possess a much lower ocv $(\mathrm{E}=0.68 \mathrm{~V}$ for $\mathrm{Ag} / \mathrm{I}_{2}$ system versus $\mathrm{E}=2.6 \mathrm{~V}$ for $\left.\mathrm{Li} / \mathrm{TiS}_{2}\right)^{5}$ but a higher discharge rate.

In the case of chemical sensors, Hötzel and Weppner have studied a chlorine gas sensor based on the following galvanic chain: $\mathrm{Pt} / \mathrm{AgCl}$ (thin film) $/ \mathrm{RbAg}_{4} \mathrm{I}_{5}$ / $\mathrm{Ag}^{6}$.

In both cases we have tried to use the silver ion conducting glasses to replace $\mathrm{RbAg}_{4} \mathrm{I}_{5}$ in these devices. 
Glasses are also well adapted to the preparation of sensitive membranes ${ }^{17}$ for ion detection, as thin films of glassy electrolytes have good stability in solution and a fixed activity for the ions to detect. This report describes the easibility of such membranes with silver ion conducting glasses for $\mathrm{Cd}^{++}$ion detection.

\section{SILVER-IODINE BATTERIES}

\subsection{Experimental}

The electrolyte was a glass of composition $0.12 \mathrm{Ag}_{2} \mathrm{~S}-0.44 \mathrm{AgI}-0.44 \mathrm{AgPO}_{3}$ prepared as described elsewhere ${ }^{3}$. The galvanic chain was as follows:

$$
\mathrm{Ag}+\text { electrolyte/electrolyte/electrolyte }+ \text { phenothiazine }+\mathrm{I}_{2}+\mathrm{C}
$$

The anode was made of $70 \mathrm{w} \%$ glass and $30 \mathrm{w} \%$ silver powder. The composition of the cathode was $24 \mathrm{w} \%$ Carbon, $16 \mathrm{w} \%$ phenothiazine, $60 \mathrm{w} \%$ iodine. Carbon was added to the cathode to insure electronic conductivity. The charge transfer complex iodine-phenothiazine was used in place of pure iodine to disperse the iodine atoms in order to avoid the formation of an ionic and electronic insulating film of $B \mathrm{AgI}^{4}$. Anode electrolyte and cathode were pressed together under $5 \mathrm{t} /$ $\mathrm{cm}^{2}$. The surface of the obtained pellet was coated with epoxy resin and then introduced in a teflon cell (Fig. 1).

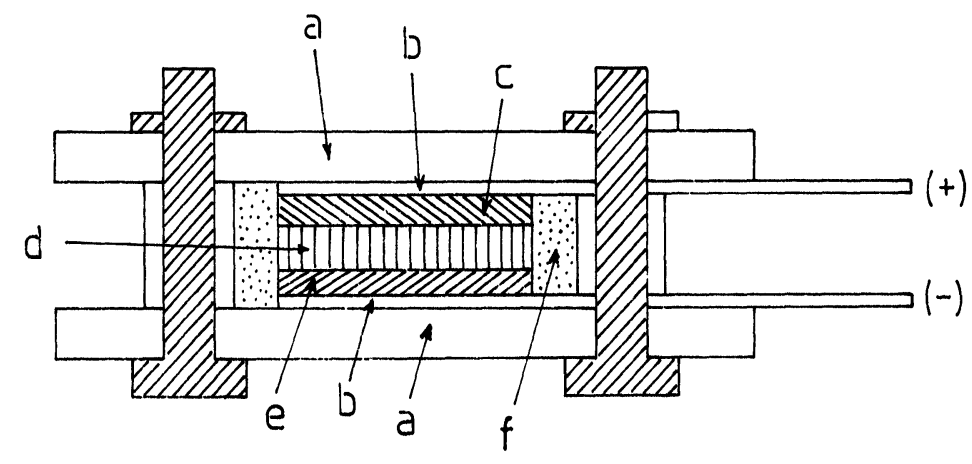

a. Insulator

b. Nickel lead

C. Cathode

d. Electrolyte

e. Anode

f. Epoxy resin

FIGURE 1 Cross section of the battery test cell. 


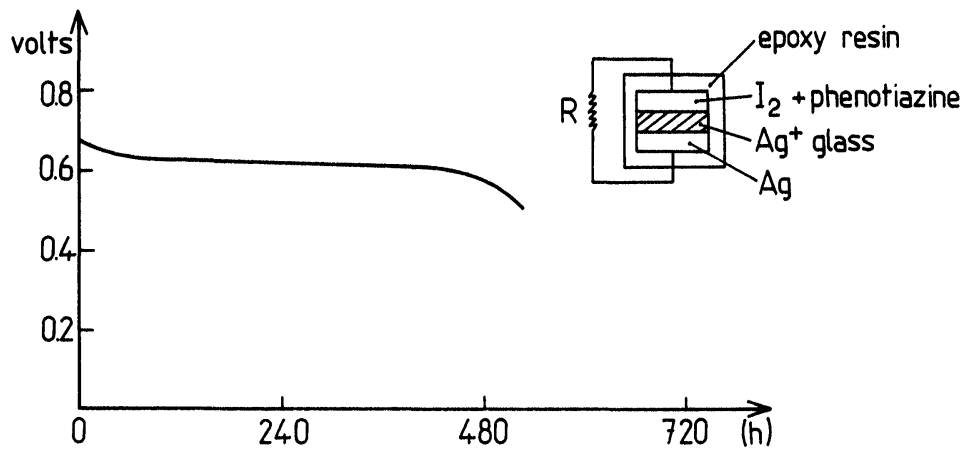

FIGURE 2 Discharge curve of the battery $\left(T=25^{\circ} \mathrm{C}\right.$, current density $\left.=10 \mu \mathrm{A} / \mathrm{cm}^{2}\right)$

\subsection{Results}

A discharge curve is displayed in Fig. 2. It corresponds to a load resistance of 47 $\mathrm{k} \Omega$ and a current density of $10 \mu \mathrm{A} / \mathrm{cm}^{2}$. In a previous study, Sun Hongwei studied a comparable galvanic chain $\left(\mathrm{Ag} / \text { electrolyte } / \mathrm{I}_{2}+\mathrm{C}\right)^{7}$, where the discharge voltage for a $2 \mu \mathrm{A} / \mathrm{cm}^{2}$ discharge current density was $0.66 \mathrm{~V}$. In our case, the plateau of the discharge curve corresponds to a slightly lowered voltage $(0.63 \mathrm{~V})$ due to the use of the charge transfer complex. However, the battery yield is about 2.5 times higher. This result is also to be compared to that obtained by Saito and Kashihara ${ }^{4}$. Under comparable discharge conditions, the lifetime of the battery using the glass electrolyte is $25 \%$ longer than with $\mathrm{RbAg}_{4} \mathrm{I}_{5}(500 \mathrm{~h}$ against $400 \mathrm{~h})$.

\section{CHEMICAL GAS SENSORS}

\subsection{Introduction}

Gas chemical sensors are becoming increasingly important in many fields; power consumption, raw material savings, industrial process improvements, pollution con-

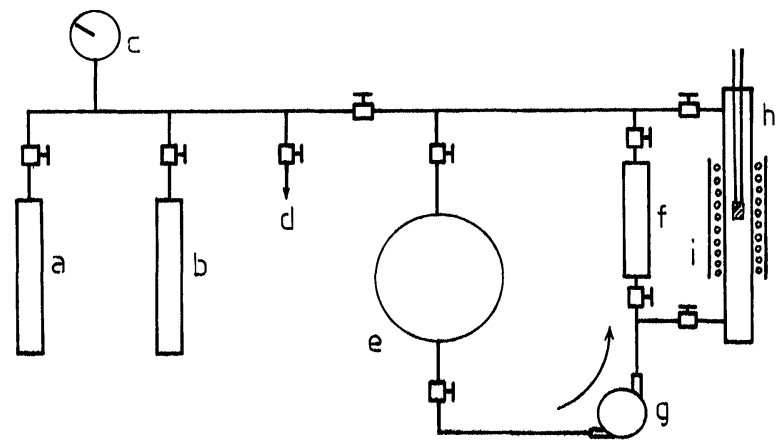

FIGURE 3 Gas line used to test the sensors: a) gas tank (high pressure), b) gas tank (low pressure), c) manometer, d) vacuum pump, e) mixture chamber, f) mixing gas device, g) cycling pump, h) test chamber, i) heater 

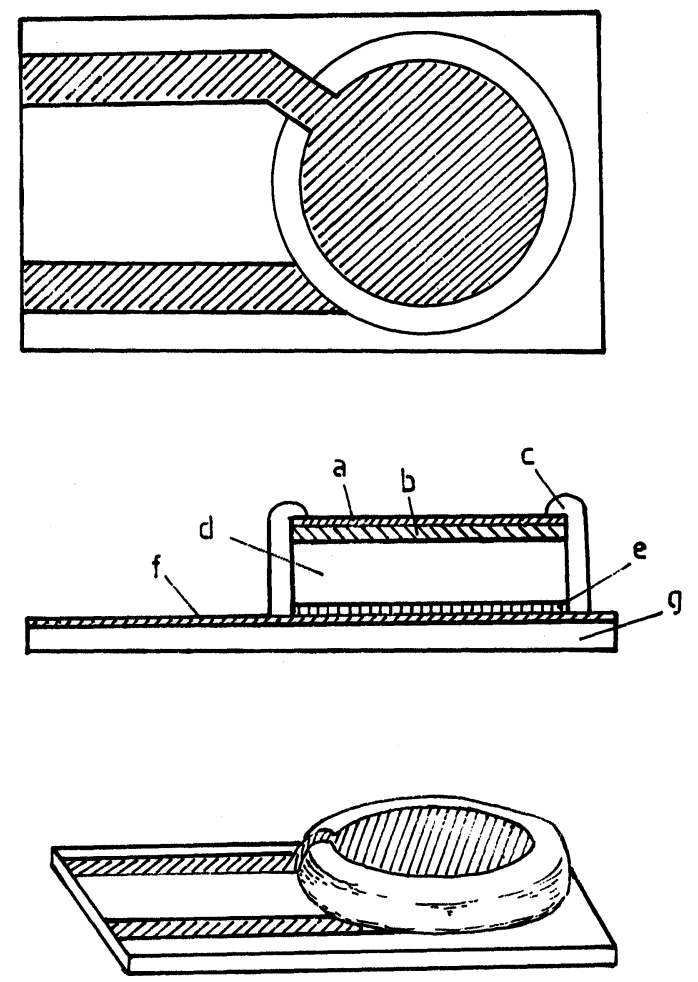

FIGURE 4 Schematic diagram of the investigated cell: a) sputtered Pt thin film, b) sputtered $\mathrm{AgCl}$ thin film, c) epoxy resin coating, d) $\mathrm{Ag}^{+}$conducting glass electrolyte, e) $\mathrm{Ag}$ reference electrode, f) Gold leaf, g) $\mathrm{Al}_{2} \mathrm{O}_{3}$ ceramic substrate

trol, etc. Among the various kinds of gas sensors in use, potentiometric ones are specially interesting due to their specific property of selectivity. However, for many applications the main drawback of potentiometric sensors is their high working temperature. A great deal of research is currently aimed at lowering this temperature ${ }^{6.8 .10}$. Oxygen sensor operating at room temperature or slightly above have been studied ${ }^{10,12}$. Sensors are also being developed industrially for other gases (i.e., $\left.\mathrm{Cl}_{2}, \mathrm{SO}_{2}, \mathrm{SO}_{3}\right)^{13,14}$. The use of an auxiliary layer was recently proposed to analyze gases that have no suitable ionic conductor materials ${ }^{6,10,15,16}$.

In our case, the galvanic cell used to detect $\mathrm{Cl}_{2}$ gas was:

$$
\mathrm{Ag} / \mathrm{Ag}^{+} \text {conducting glass } / \mathrm{AgCl}, \mathrm{Pt}, \mathrm{Cl}_{2}
$$

Ag metal forms a reference electrode and the $\mathrm{Ag}^{+}$conducting glass is the electrolyte. $\mathrm{AgCl}$ acts as an auxiliary layer and $\mathrm{Pt}$ is the measurement electrode. The electrode reaction is:

$$
\mathrm{Cl}_{2}+2 \mathrm{Ag} \longrightarrow 2 \mathrm{AgCl}
$$




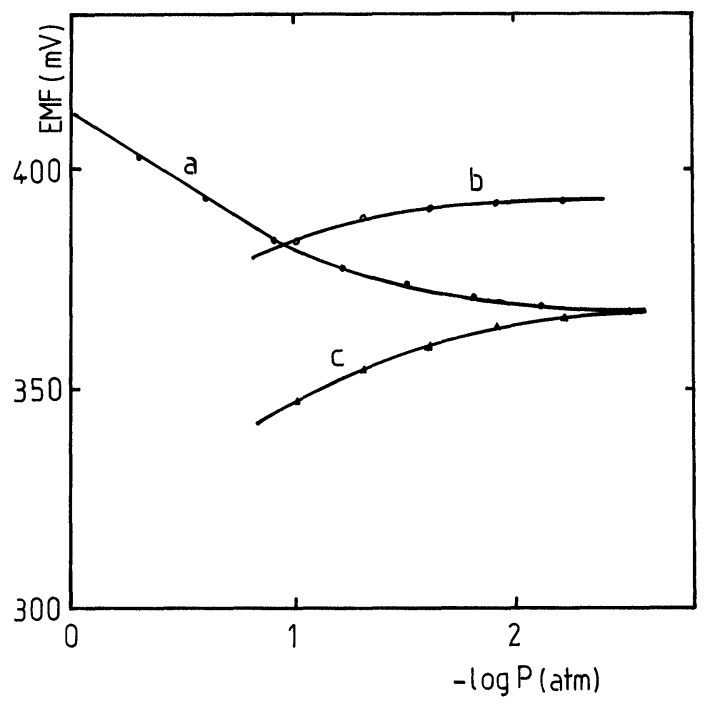

FIGURE 5 Sensor $\mathrm{Ag} / \mathrm{Ag}^{+}$(glass) $/ \mathrm{Pt}$. Response: a) oxygen-argon at $93^{\circ} \mathrm{C}$, b) $\mathrm{H}_{2} \mathrm{~S}$-air at $92^{\circ} \mathrm{C}, \mathrm{c}$ ) $\mathrm{H}_{2} \mathrm{~S}$-argon at $81^{\circ} \mathrm{C}$.

According to Nernst's law, the e.m.f. obeys the equation: $E=E_{0}+(k T / n q)$ In $\mathrm{PCl}_{2}$ with $\mathrm{k}=$ Boltzmann constant, $\mathrm{q}$ the electron charge, $\mathrm{T}$ the temperature and $\mathrm{n}=2$ is the number of electrons involved in the electrode reaction, $\mathrm{E}_{0}$, the standard potential, can be calculated from the Gibbs energy of $\mathrm{AgCl}$.

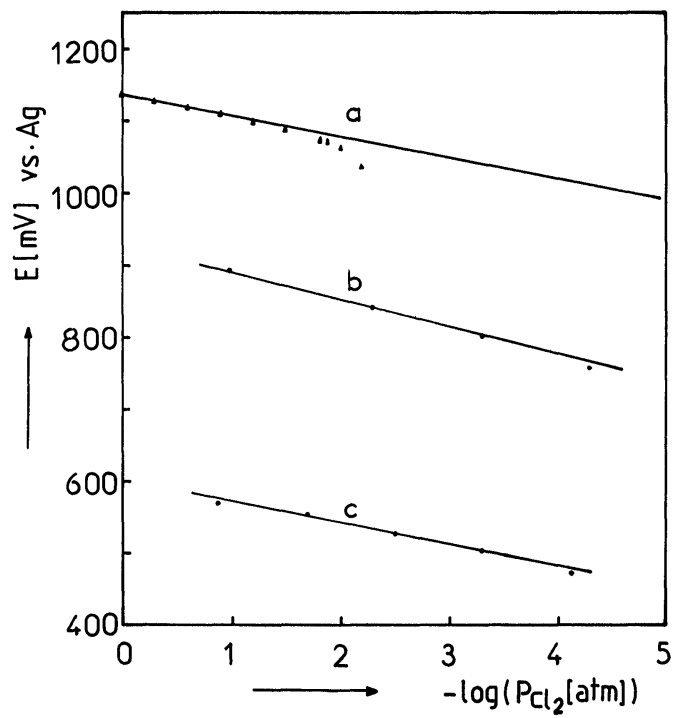

FIGURE 6 Variation of the EMF versus chlorine partial pressure $\left(T=25^{\circ} \mathrm{C}\right)$ a) pure $\mathrm{AgCl}$ sensor, b) sensor coated with $\mathrm{AgCl}$ thick film, c) sensor coated with $\mathrm{AgCl}$ thin film. 


\subsection{Experimental}

$\mathrm{Cl}_{2}$ gas was obtained from UCAR (Research purity) and the gas line used in this study is shown in Fig. 3.

The sensor device is depicted in Fig. 4. AgI- $\mathrm{Sb}_{2} \mathrm{~S}_{3}$ glass was used as a solid electrolyte. The measurement electrode was made by a sputtered $\mathrm{AgCl}$ film coated with a sputtered $\mathrm{Pt}$ film. A pellet of silver powder was co-pressed with the electrolyte as the reference electrode. The sensor was then sealed using epoxy resin to avoid any reaction of the reference electrode with the gas atmosphere. A sputtered $\mathrm{Pt}$ electrode and gold leads on an $\mathrm{Al}_{2} \mathrm{O}_{3}$ ceramic substrate were used. The gas-carrier was Argon or air. The sensor e.m.f. was measured for various gas concentrations with a high-input-impedance $\left(10^{14} \Omega\right)$ Keithley 16 multimeter.

\subsection{Results}

3.3.1 Response to $\mathrm{O}_{2}$ and $\mathrm{H}_{2} \mathrm{~S}$ gases. Oxygen response was first tested in the simple galvanic cell $\mathrm{Ag} / \mathrm{Ag}$ conducting glass/Pt. A variation of the e.m.f. was observed due to the formation of a $\mathrm{Ag}_{2} \mathrm{O}$ film at the surface of the electrolyte. The experimental curve is shown in Fig. 5a. For high oxygen concentration, the e.m.f. varies linearly with the logarithm of oxygen partial pressure. However, at low oxygen pressure the line slope changes. This behavior could be due to a kinetic adsorption effect. Indeed, at room temperature the response time increases.

The sensitivity to $\mathrm{H}_{2} \mathrm{~S}$ has been also tested. In air, when the partial pressure of $\mathrm{H}_{2} \mathrm{~S}$ is lower than $10^{-2}$ atm. (Fig. 5b) the e.m.f. value corresponds to the response at $\mathrm{P}_{\mathrm{O}_{2}}=0.21$ atm., which is the partial pressure of oxygen in air (Fig. 5a). When $\mathrm{H}_{2} \mathrm{~S}$ is mixed with Argon (Fig. 5c) with $\mathrm{P}_{\mathrm{H}_{2} \mathrm{~S}}<10^{-2}$ atm, the e.m.f. approaches a value corresponding to that of $\mathrm{P}_{\mathrm{O}_{2}}$ at the same pressure in Argon mixture (Fig. $3 a)$. These results show that this device cannot be used to detect traces of $\mathrm{H}_{2} \mathrm{~S}$ in air.

3.3.2 Response to chlorine. The chlorine response of the $\mathrm{AgCl}$ sensitive layer

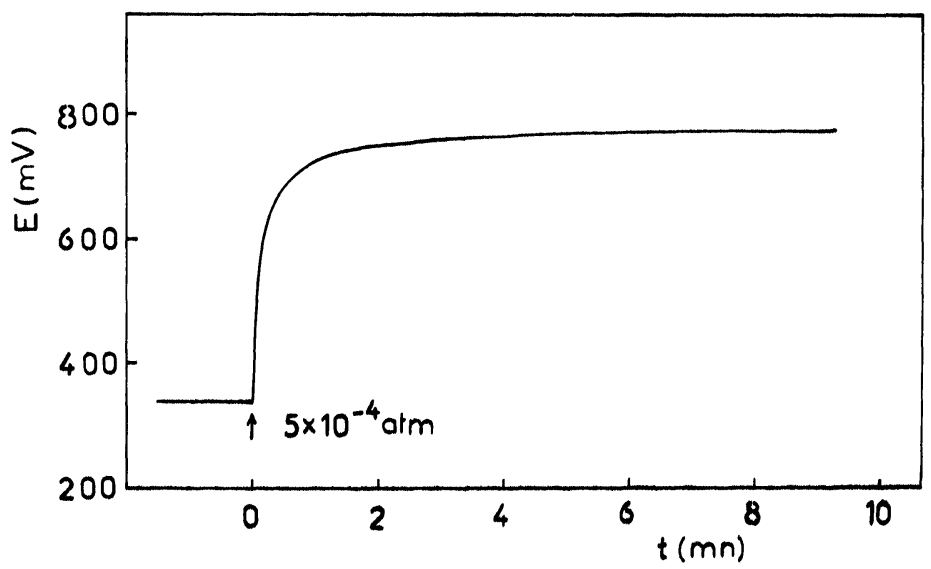

FIGURE 7 Voltage response to addition of chlorine at a pressure of $5.10^{-4}$ atm. 
(1000 $\AA$ thick) coated galvanic cell is given in Fig. $6 \mathrm{c}$. In the pressure range above $10^{-4}$ atm a linear variation is observed. At lower pressure the linear relationship is no longer obeyed due to a slow absorption kinetics.

Even in the linear domain the e.m.f. is lower than the potential expected from Nernst's law, indicating an extra chemical reaction between the electrolyte and chlorine due to the permeability of the silver chloride film. Consequently, another test was undertaken with a sensor coated with a thick (about $1 \mu \mathrm{m}$ ) $\mathrm{AgCl}$ film. The results are shown in Fig. 6b. The experimental values approach theoretical data. In a limited case a sensor using a pure $\mathrm{AgCl}$ layer as electrolyte was tested. For high $\mathrm{Cl}_{2}$ pressure the response is very near the theoretical value (Fig. 6a), while for chlorine partial pressure lower than $10^{-1}$ atm, the e.m.f. deviates due to the poor ionic conductivity of silver chloride at room temperature.

These results show that the conducting glass that contains $\mathrm{I}^{-}$ions may react with $\mathrm{Cl}_{2}$. The reaction can be as follows:

$$
2 \mathrm{I}^{-} \text {(glass) }+\mathrm{Cl}_{2} \longrightarrow 2 \mathrm{Cl}^{-}+\mathrm{I}_{2}
$$

As the sensor e.m.f. depends on the activity of the gas at the electrolyte surface (i.e., at the "triple contact" gas/electrolyte/electronic conductor), the potential is lower than that given by Nernst's law using Gibbs energy of formation of $\mathrm{AgCl}$.

With a thick $\mathrm{AgCl}$ film, the response time is less than $3 \mathrm{~mm}$ for a chlorine partial pressure of $5 \times 10^{-4}$ atm (Fig. 7). At lower pressure the response time becomes longer and the e.m.f. variation is no longer linear.

\section{ISFET SENSITIVE MEMBRANES}

Chalcogenide and derived chalcohalide glasses have already been used to prepare selective electrodes ${ }^{17-20}$. Their properties are well adapted to this kind of application; low solubility in water, good ionic and very low electronic conductivities, and a wide range of composition ${ }^{2-3,21}$ permitting the preparation of various membranes. They are potentially interesting as membranes for ISFET (insulator semiconductor field effect transistors) devices as it appears possible to prepare thin films of various glasses having a constant activity for the ions detection and a sufficient ionic conductivity $\left(\mathrm{Ag}^{+}, \mathrm{Li}^{+}\right.$or other ions . . .) to obtain good performances.

We now present the preparation and performance of a thin film chalcogenide glass used as sensitive membrane for cadmium detection.

\subsection{Membrane Preparation}

A chalcogenide circular target ( $50 \mathrm{~mm}$ diameter, $4 \mathrm{~mm}$ thickness) was first fabricated by grinding and mixing ultrapure powders (Merck products) with the composition ${ }^{17} 57 \mathrm{As}_{2} \mathrm{~S}_{3}, 38 \mathrm{Ag}_{2} \mathrm{~S}, 5 \mathrm{CdS}$ (moles \%). The mixture was pressed under $1 \mathrm{~T} / \mathrm{cm}^{2}$ and then heated at $220^{\circ} \mathrm{C}$ in a vacuum chamber $\left(5 \times 10^{-7} \mathrm{Torr}\right)$. Chalcogenide thin films were prepared by RF magnetron sputtering of this target in an argon gas plasma at a pressure of $10^{-2}$ Torr, which an incident powder of $25 \mathrm{~W}$ and a deposition rate of $20 \mathrm{~A}^{\circ} / \mathrm{mn}$. 


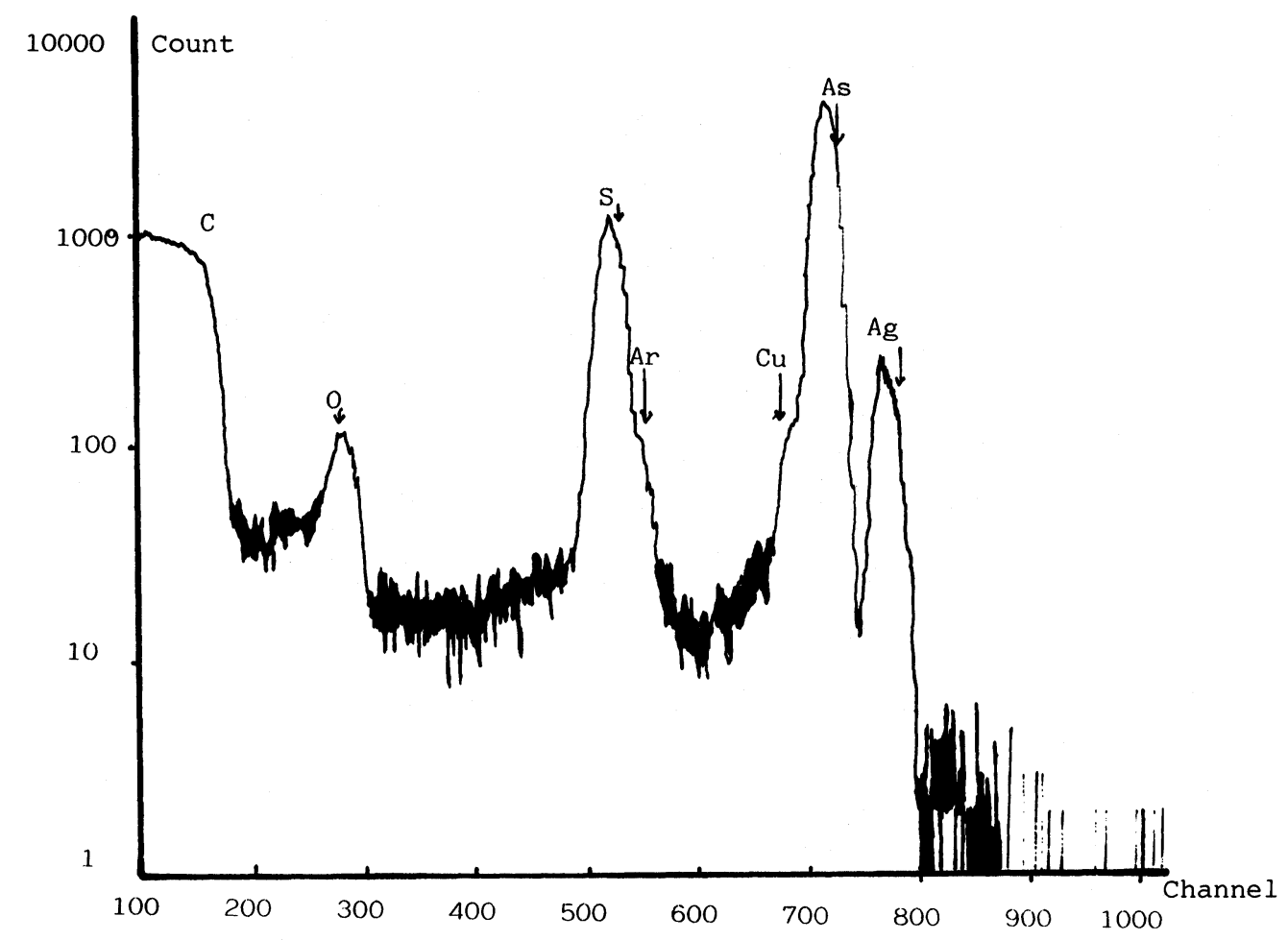

R.B.S thin fi]m spectrum ('Thickness $=400^{\circ}$ )

\begin{tabular}{c|l|c|c|} 
& $\mathrm{N}_{\mathrm{S}} / \mathrm{N}_{\mathrm{As}}$ & $\mathrm{N}_{\mathrm{S}} / \mathrm{N}_{\mathrm{Ag}}$ & $\mathrm{N}_{\mathrm{O}} / \mathrm{N}_{\mathrm{S}}$ \\
\hline Théo. & 1.88 & 2.82 & 0 \\
\hline Expé. (1) & 1.56 & 13.96 & 0.45 \\
\hline Expé. (2) & 1.18 & 115.2 & 0.50 \\
\hline
\end{tabular}

(2): one month target age

FIGURE 8 Study of the composition of a glass film by Rutherford Backscattering

Even heated at $420^{\circ} \mathrm{C}$ the films appear amorphous. The composition of the films has been studied by RBS (Rutherford back scattering) using $2 \mathrm{MeV} \alpha$ particles. A typical spectrum is given in Figure 8. The film composition appears different from the one of the target. Moreover, a decrease of the sulfur and silver concentrations accompanying some aging process of the target has been observed. Con- 


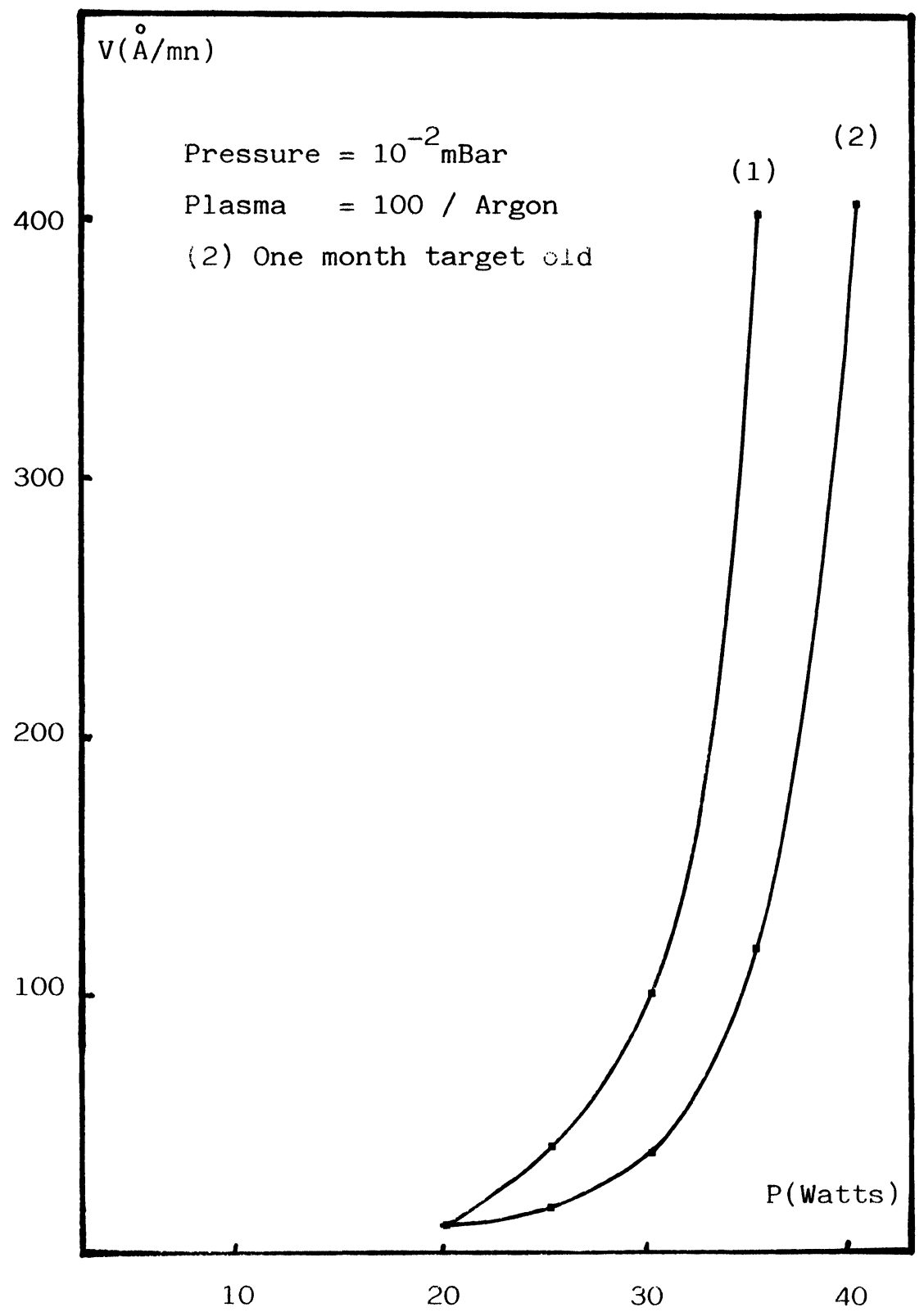

FIGURE 9 Deposition rate versus RF power for 1) new target 2) one month old target

currently, the deposition rate decreases (Fig. 9). A glassy target would probably give a better behavior than the one made of pressed powder.

Thin film symmetrical cells $\mathrm{Au} /$ glass/Au have been prepared to perform admittance spectroscopy study. The obtained frequency response has been used to calculate the ionic conductivity at room temperature: $\sigma_{300 \mathrm{~K}}=2.510^{-12}{\mathrm{~S} . \mathrm{cm}^{-1}}^{-}$. 


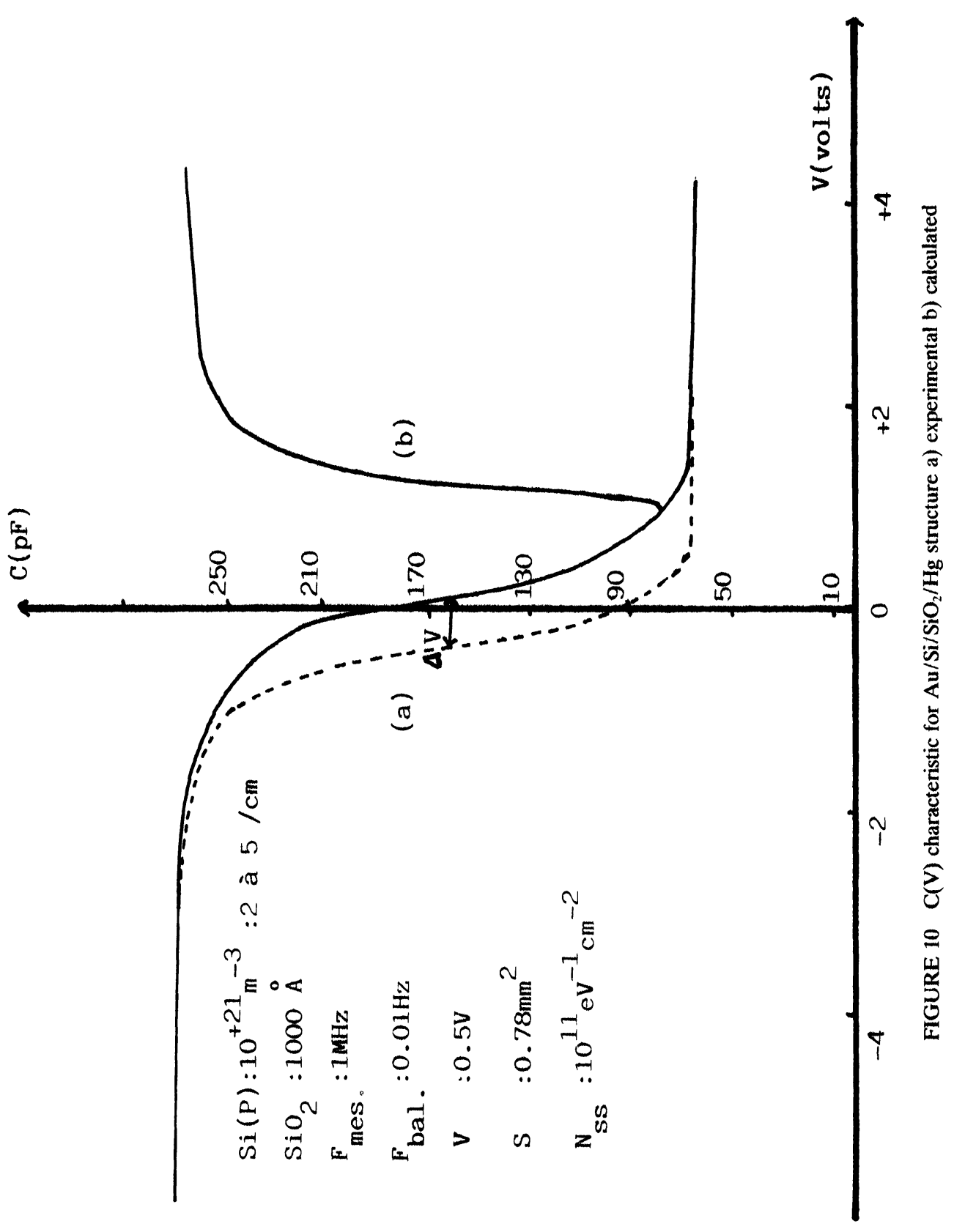




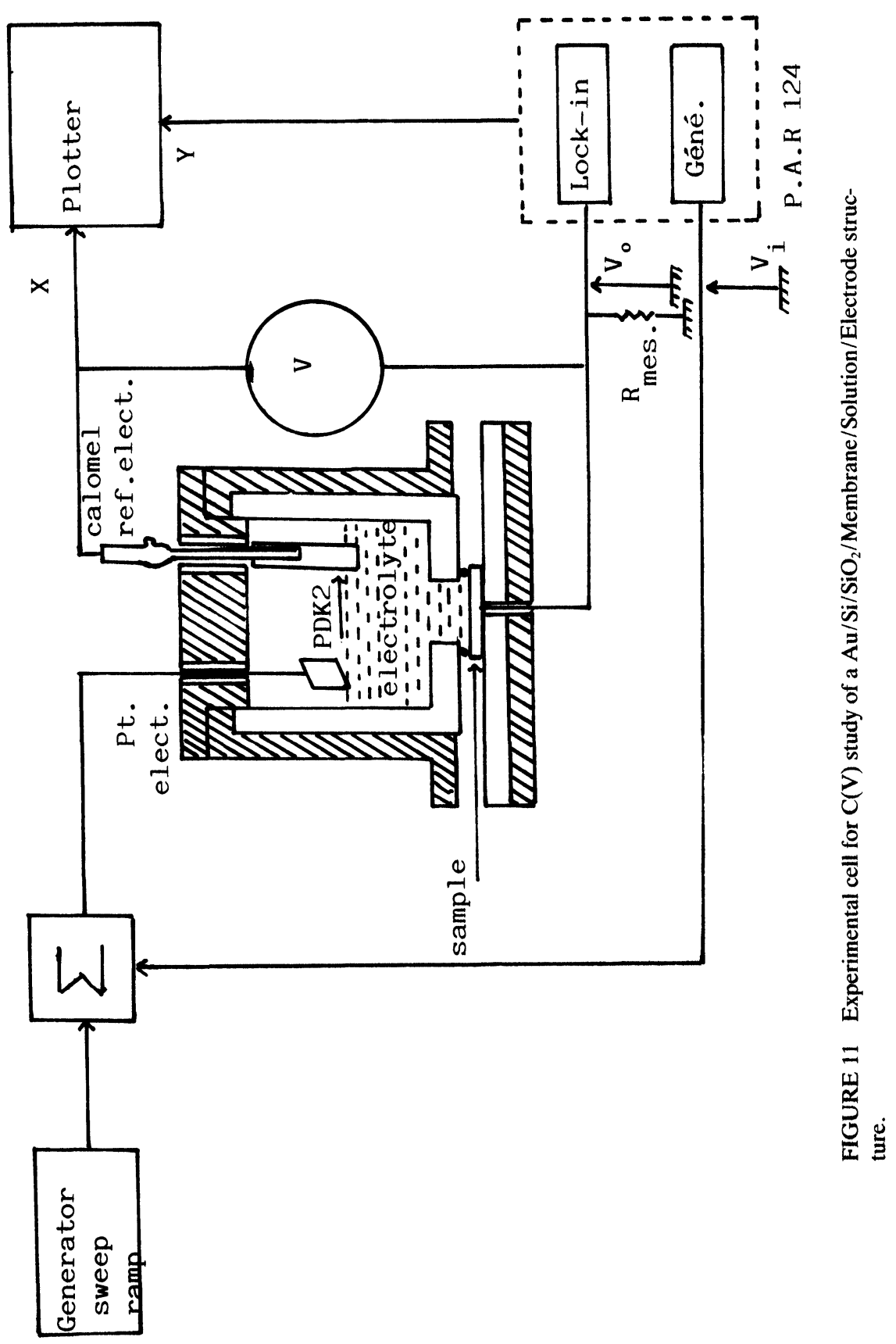


LIU JUN et al.

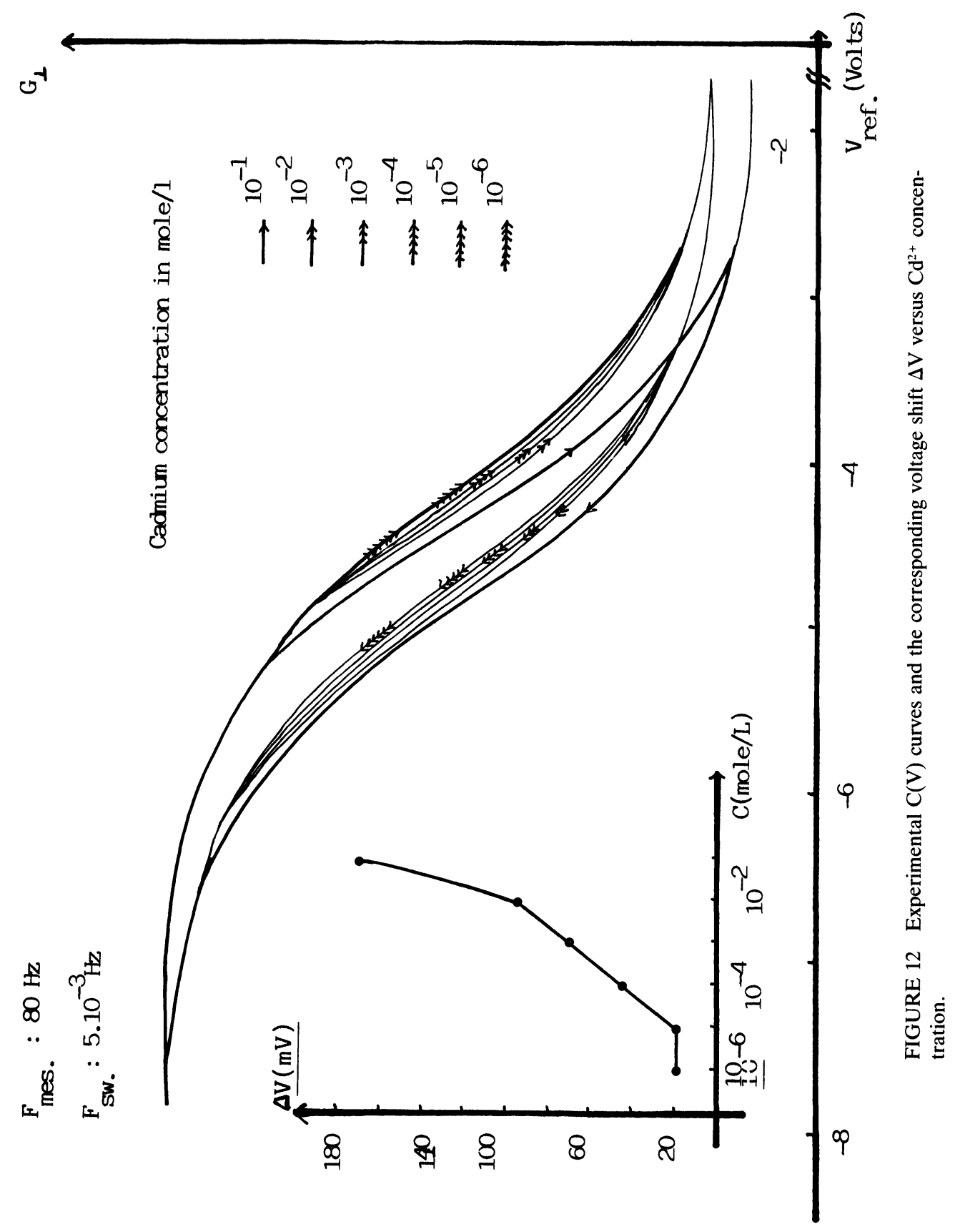




\subsection{Membrane Characterization: $C(V)$ Study}

To determine whether the glass films could be used as ISFET membranes, we have studied the $\mathrm{C}(\mathrm{V})$ response of $\mathrm{Au} / \mathrm{Si} / \mathrm{SiO}_{2} / \mathrm{Membrane} /$ Ions in Solution/Electrode cells. The $\mathrm{Si} / \mathrm{SiO}_{2}$ wafers, provided by LETI (Grenoble, France*), were prepared with $\mathrm{p}$ type silicon at a doping density about $10^{21} \mathrm{~m}^{-3}$ and a $\mathrm{SiO}_{2}$ thickness of 1000 $\AA$.

Preliminary measurements: As a basis for our analysis we first studied the $\mathrm{C}(\mathrm{V})$ response of the structure $\mathrm{Au} / \mathrm{Si} / \mathrm{SiO}_{2} / \mathrm{Hg}$ before the membrane deposition. The study was performed with a Boonton capacitance meter at $1 \mathrm{MHz}$. The corresponding curve is given in Fig. 10 and can be compared to the $\mathrm{C}(\mathrm{V})$ response of the $\mathrm{Au} / \mathrm{Si} / \mathrm{SiO}_{2} / \mathrm{Membrane} / \mathrm{Hg}$ structure. It shows important voltage shifts (due in part to the in-series addition of the impedance of the membrane and in part to states and charges created by sputtering) and the need for a low frequency study $(\leq 100 \mathrm{~Hz})$ in order to obtain the complete accumulation process (due to the ion response time consant in the membrane).

Studying Cadmium detection: The Cadmium detection ability of the chalcogenide membrane has been tested by studying the $\mathrm{C}(\mathrm{V})$ response at low frequencies of a $\mathrm{Au} / \mathrm{Si} / \mathrm{SiO}_{2} / \mathrm{Membrane} /$ solution/electrode structure. Figure 11 shows the experimental cell we have used. The applied ac signal frequency was in the range 2 to $200 \mathrm{~Hz}$ and the scanning rate from 0.0001 to $1 \mathrm{Vs}^{-1}$. The real and imaginary parts of the current were measured by using a PAR model 124 Lock-in Amplifier. Various buffer solutions have been tested with $\mathrm{pH}$ ranging from 1.679 to 9 . The desired $\mathrm{Cd}^{++}$concentration was obtained by adjonction of $\mathrm{Cd}\left(\mathrm{NO}_{3}\right)_{2}$ to the solution. The most significant and reproducible results (Fig. 12) have been obtained with the Tacussel buffer solution TRIS of $\mathrm{pH} 9$. We can observe a constant slope $(25 \mathrm{mV} /$ decade) of the curve giving the voltage shift $\Delta \mathrm{V}$ of the $\mathrm{C}(\mathrm{V})$ characteristics versus the log of the $\mathrm{Cd}^{++}$concentration in the range $10^{-5}$ to $10^{-2}$ mole ${ }^{-1}$. This shift must be the result of an equilibrium for $\mathrm{Cd}^{++}$ions at the surface of the membrane.

\section{CONCLUSION}

This study shows the feasibility of silver conducting glasses as electrolytes in electrochemical devices. Easy to prepare and to shape, and having a good chemical durability, they can replace $\mathrm{RbAg}_{4} \mathrm{I}_{5}$ as an electrolyte in electrochemical devices, or act as sensitive membranes in chemical sensors.

\section{ACKNOWLEDGMENTS}

This work has been partly supported by the "Comité Capteurs" of the French Ministry of Research and Technology.

The authors wish to thank Dr. R. Castellano, editor, Active and Passive Electronic Components, for very helpful discussions.

\section{REFERENCES}

1. J.M. Reau, B. Tanguy, J.J. Videau, J. Portier and P. Hagenmuller, Solid State Ionics 28 (1986) 782. 
2. H.W. Sun, B. Tanguy, J.M. Réau, J.J. Videau and J. Portier Mat. Res. Bull. 22 (1987) 823.

3. Liu Jun, J. Portier, B. Tanguy, J.J. Videau and C.A. Angell Solid State Ionics, 34 (1989) 87.

4. S. Saito and S. Kashihara in "Applications of solid electrolytes" T. Takahashi and A. Kozawa ed. JEC Press 1980.

5. S. Sinha and D.W. Murphy, Solid State Ionics 20 (1986) 81.

6. G. Hötzel and W. Weppner, Solid State Ionics 18-19 (1986) 1223.

7. Sun Hongwei Thesis University of Bordeaux I, 1986.

8. J. Fouletier Sensors and Actuators 3 (1982-83) 295.

9. G. Velasco, J. P. Schnell and M. Croset Sensors and Actuators 2 (1982) 371.

10. J. Salardenne, F. Labidi, D. Birot, Solid State Ionics 28-30 (1988) 1648.

11. Wang Yong-Neng, Tan Fu-Bin and Jia Neng-Cheng, Solid State Ionics 22 (1987) 151.

12. N. Miura, J. Hisamoto, N. Yamazoe, S. Kuwata and J. Salardenne Sensors and Actuators 16 (1989) 301.

13. M. Gauthier, A. Belanger, Y. Méas and M. Kleitz in Solid Electrolytes, P. Hagenmuller and W. Van Gool eds. Academic Press, New York (1978) 497.

14. M. Kleitz, A. Pelloux and M. Gauthier in Fast Ion Transport in Solids P. Vashita, J.N. Mundy and G.K. Shenoy eds. New York (1979) 69.

15. J. Salardenne, F. Labidi, J. Portier, D. Birot in Proc. of the 2nd Intern. Meet. on Chemical Sensors Bordeaux (1986) 323.

16. W. Weppner Sensors and Actuators 12 (1987) 107.

17. Y.G. Vlassov, E. A. Bychkov, Zhu. Anal. Khim., 40, nº, 1438 (1986) and in Proc. of the 2nd Intern. Meet. on Chemical Sensors, Bordeaux France 1986, p 495.

18. I. Trachtenberg and co-workers J. Electrochem. Soc. 118 (1971) 329, 120 (1973) 1169 and 121 (1974) 363.

19. A. E. Owen J. Non Cryst. Solids 35-36 (1980) 999.

20. C. Bohnke, A. Saîda and G. Robert, C.R. Acad. Sc. Paris C290 (1980) 97 and Electrochem. Acta 26 (1981) 1137.

21. H.W. Sun, B. Tanguy, J.M. Reau, J.J. Videau, J. Portier, P. Hagenmuller J. of Solid State Chem. 70 (1987) 141. 

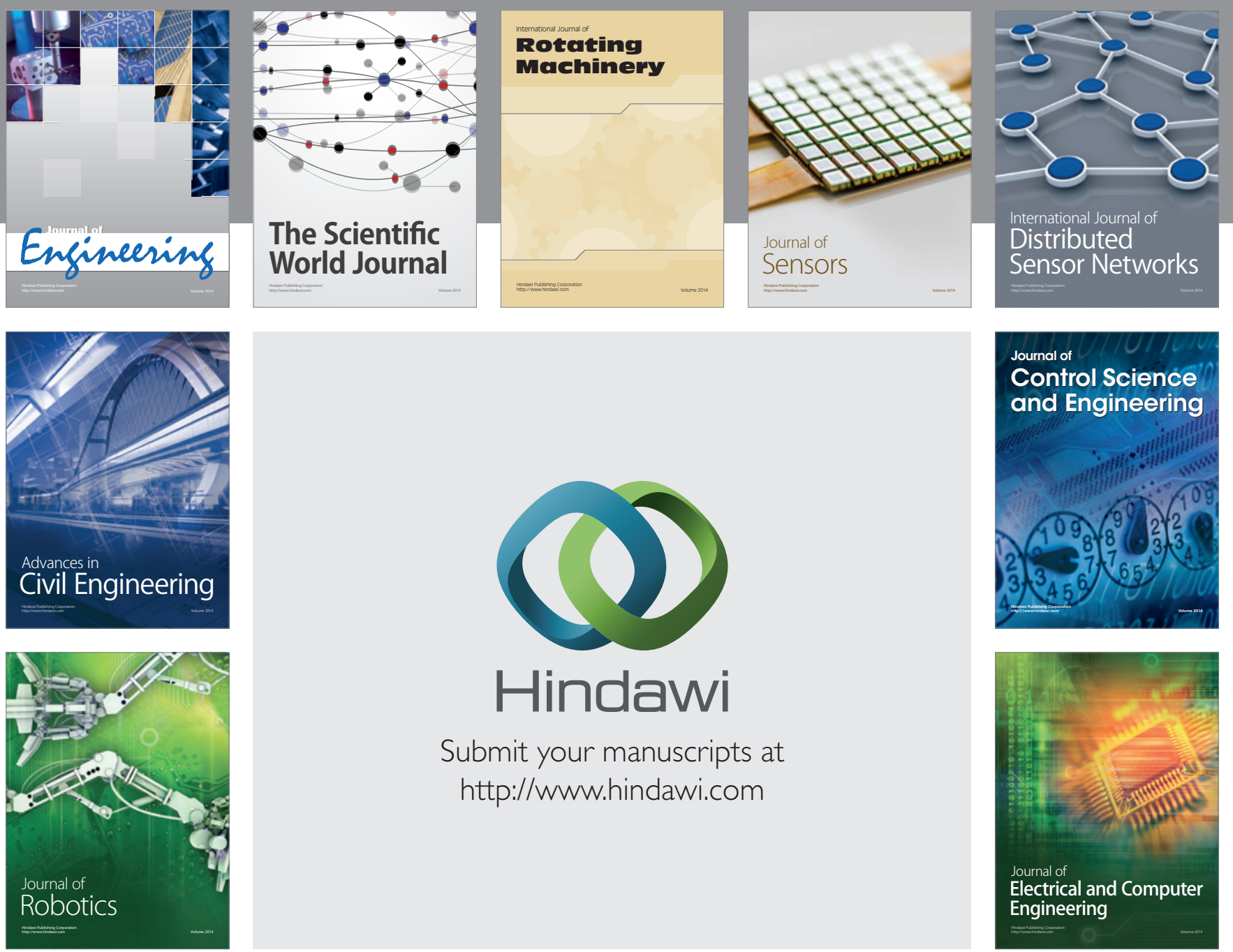

Submit your manuscripts at

http://www.hindawi.com
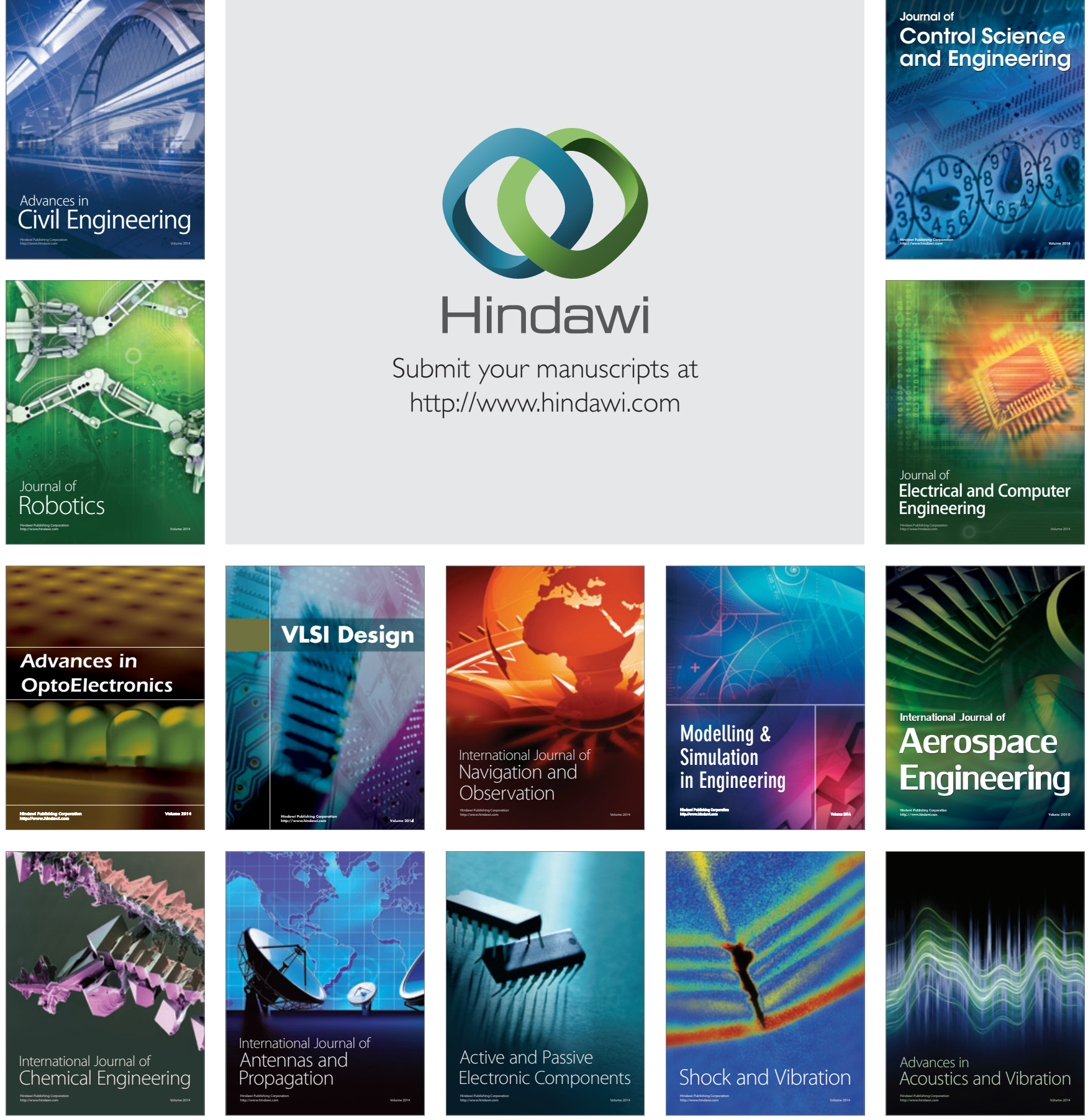